\title{
WHO WANTS TO DO BUSINESS?
}

\author{
Alice Reissová ${ }^{1}$ \\ Jana Šimsová ${ }^{2}$
}

DOI: https://doi.org/10.31410/LIMEN.S.P.2019.105

\begin{abstract}
Entrepreneurship is considered the main driving force of economic growth and innovation. Thus, it is important to monitor the interest of young people in starting a business. The aim of this paper is to find out which main variables influence starting of a business by university students. A decision tree (n=1168) was used to identify these variables. It was found that the type of university and gender play an important role. Students of the Faculty of Arts and Design, the Faculty of Social and Economic Studies and the Faculty of Mechanical Engineering want to start a business most frequently. It was also proved that men claim to be more interested in entrepreneurship than women. However, it is very interesting to find that there are no statistically significant gender differences between students that already have a business.
\end{abstract}

Keywords: Interest, Entrepreneurship, Factors which influence starting a business, Type of university, Gender.

\section{INTRODUCTION}

G

overnments of individual countries encourage entrepreneurship because it brings extensive economic profit; it is a potential source of innovation, a driving force for economic growth, and it creates new jobs. From the perspective of young people, entrepreneurship is one of ways in which to assert oneself on the labour market. The willingness to do business is influenced by a number of factors. An extensive study was carried out by Belás, Ključnikov and Smrčka (2016) with the purpose of identifying the most important incentives for starting a business. In a sample of more than one thousand businesspersons they established that the most important incentives for people to start a business are financial incentives and a strong incentive appeared to be entrepreneurship as a mission. Some businesspersons state they started business because they had no other job. Apparently, entrepreneurship as an alternative for improving one's labour market prospects is a realistic presumption. This incentive will apparently be more dominant in developing economies and in advanced countries in specific phases of the economic cycle when the economy slows down and employers do not wish to recruit new employees or even make them redundant. Other authors (such as Campin, Barraket, \& Luke, 2013) also mention the fact that financial incentives do not play a primary role in starting a business. On the other hand, the conclusions of some studies identify economic factors as important factors, however, not the only ones. They are very closely linked to other incentives, such as self-efficacy, independence, personal ambitions and others (Hessels, Gelderen, Thurik, R., 2008; Chen, \& Elston, 2013; Herring \& Willie 2019).

The question is, how can education influence entrepreneurial intentions. Nabi et al. (2018) investigate whether entrepreneurial education subsequently influences entrepreneurial intentions. They conclude that the results are not clear or explicit. Entrepreneurial education may have a

\footnotetext{
1 Department of Economy and Management of the Faculty of Social and Economic Studies, Jan Evangelista Purkyně University, 40096 Ústí nad Labem, Czech Republic

2 Department of Mathematics and Statistics of the Faculty of Social and Economic Studies, Jan Evangelista Purkyně University, 40096 Ústí nad Labem, Czech Republic
} 
positive influence on the subsequent business plan; however, a negative influence has been established as well. The most positive influence appears to be entrepreneurship education in the first years of university education.

Raza and Irfan (2017) recommend that schools focus particularly on the development of students' intentions, self-efficacy and motivators relating to the development of entrepreneurial intentions.

Some authors think that the decision to start a business is made by young people at the time prior to entering the labour market (Yildiz, 2018). Consequently, the objective of this research was to identify entrepreneurial intentions of university students and variables related to the intentions.

\section{METHODOLOGY}

To achieve the objective, a written questionnaire was used. The survey group consisted of students from all faculties of the Jan Evangelista Purkyně University in Ústí and Labem (Czech Republic). An overview of the faculties (including their abbreviations used in the text below) is shown in Table 1.

Table 1. Faculties included in the research

\begin{tabular}{|l|l|}
\hline Abbreviation & Name of faculty \\
\hline FSES & Faculty of Social and Economic Studies \\
\hline FEd & Faculty of Education \\
\hline FS & Faculty of Science \\
\hline FHS & Faculty of Health Studies \\
\hline FME & Faculty of Mechanical Engineering \\
\hline FEnv & Faculty of the Environment \\
\hline FA & Faculty of Arts \\
\hline FAD & Faculty of Art and Design \\
\hline
\end{tabular}

Source: own

The size of the selection group at individual faculties was specified using the quota sampling in consideration of the number of involved students. The selection group consisted of 1168 students. The method applied was a written questionnaire. Students answered the question on whether they are planning to do business within 3 to 5 years after finishing education. Responses were marked on the Likert scale, with 1 meaning strongly agree, 2 agree, 3 disagree and 4 strongly disagree. Students already doing business could use mark 5.

Two hypotheses were defined in the framework of the research:

Hypothesis One: planning to start a business is influenced by the type of university where a student study;

Hypothesis Two: men plan their own business more frequently than women.

MS Excel followed by SW Statistica and SPSS Statistics were used to evaluate the data. The statistical methods used for the research were the decision tree and two binomial distribution concordance parameter tests. The decision tree was used to establish what variables influence planning to start a business. The dependent variable was the variable "I want to start a business", grouped in two categories (Yes, No). The selected independent variables were: gender, mode of study (master's, bachelor), faculty and year of study. 


\section{RESULTS}

The model in Figure 1 shows that the variables mode of study and year of study do not have any influence on the decision of whether a student plans or does not plan to go into business after finishing education.

Figure 1. Decision tree - identification of variables which have an influence on planning to start a business

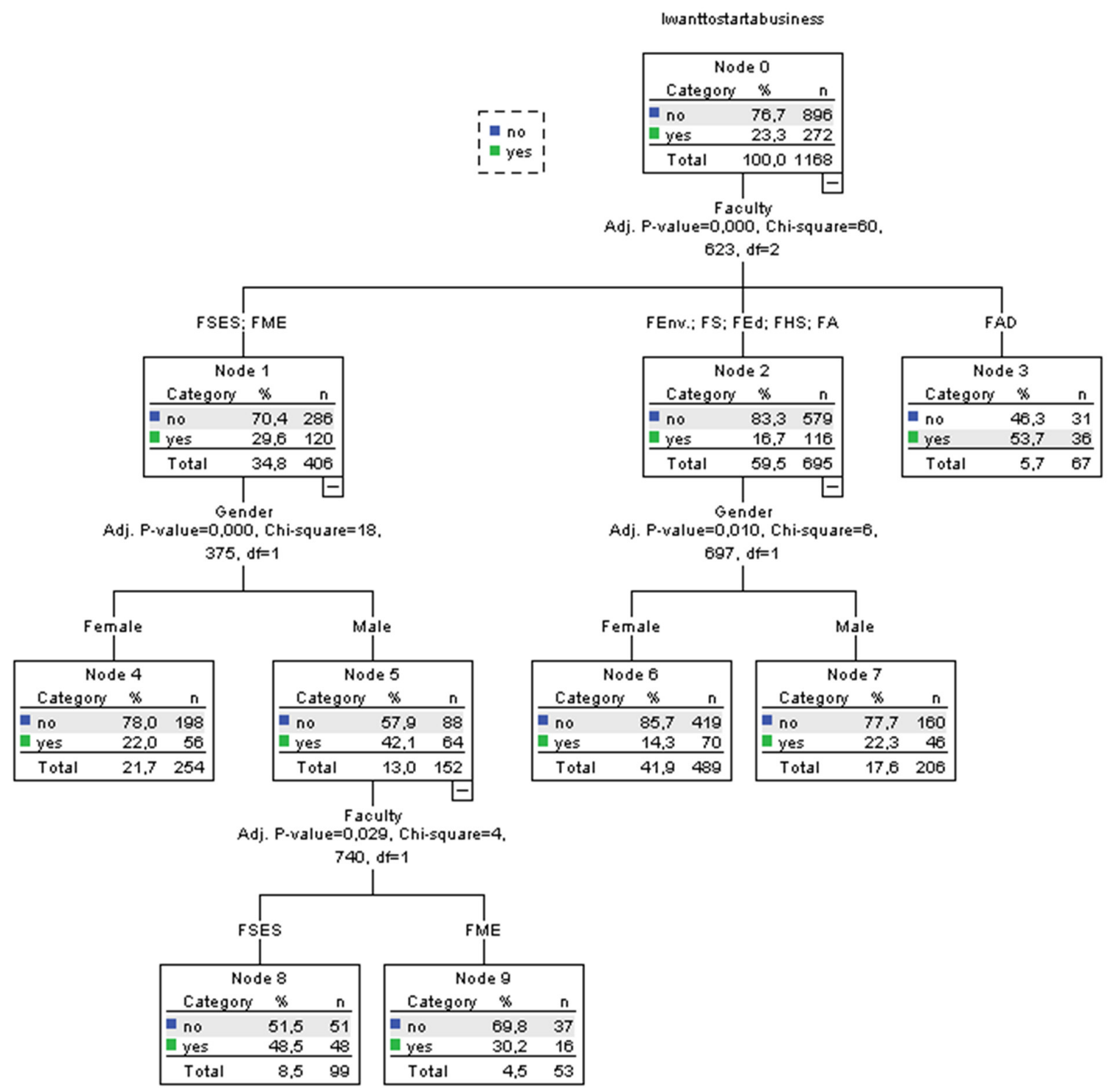

Source: own

In this model, $77.1 \%$ of cases were well classified and the risk estimate was $22.9 \%$. The variable which has the greatest influence on the interest in starting a business is the type of faculty a student currently studies at. The attitude of respondents from different faculties to the preference of being self-employed divided the model into three groups. The largest group was constituted of the group of faculties (FA, FS, FHS, FEnv and FEd). The group displays the largest number of those who are not going to start a business after finishing education (83\%). Only $16.7 \%$ of students from the first group expressed a willingness to start a business after graduating. Students who declare an interest in entrepreneurship are rather men $(22.3 \%)$ than women $(14.3 \%)$. 
The second group comprises two faculties (FSES and FME) with a slightly lower number of those who are not entrepreneurially oriented after university (70 \%). 30\% of students declare an interest in entrepreneurship in the second group. It comprises a higher number of men (42.1\%) than women ( $22 \%)$ of those willing to go into business.

The third group contains the FAD, where more than $53 \%$ of students consider starting a business after finishing education. It was established that gender has no influence on the decision to start a business after study in the students of this faculty.

It can be concluded from the foregoing findings that the formulated hypothesis:

H1: planning to start a business is influenced by the type of university where a student study was confirmed.

The second hypothesis presumed that men plan their own entrepreneurship more frequently than women. The findings stated above show that there are gender differences in the extent of intentions to start a business, not only among students of individual faculties, but also between genders at these faculties. Absolute frequencies are shown in Table 2.

Table 2. Who is interested in starting a business - gender differences

\begin{tabular}{|l|c|c|c|}
\hline $\begin{array}{l}\text { Are you going to start a business after leaving } \\
\text { university? }\end{array}$ & Female & Male & Total \\
\hline Strongly agree & 22 & 20 & 42 \\
\hline Agree & 115 & 90 & 205 \\
\hline Disagree & 411 & 195 & 606 \\
\hline Strongly disagree & 229 & 61 & 290 \\
\hline I already do business & 16 & 9 & 25 \\
\hline Total & 793 & 375 & 1168 \\
\hline
\end{tabular}

Source: own

To establish whether there are statistically significant differences in the number of males and females who do not do business yet but consider doing business, the parameter concordance of two binomial distributions test was used. The established p-value was 0.0000 . The concordance is rejected at $5 \%$ of the level of significance. This means that there is a statistically significantly higher number of men considering entrepreneurship than women.

Hypothesis "H2: men plan their own entrepreneurship more frequently than women" is therefore confirmed from the point of view of students not already doing business.

It was also looked into whether there are statistically significant gender differences between students who already do business (i.e., already during their studies). It was tested whether there are more men than women who already do business. The established $\mathrm{p}-\mathrm{value}$ of 0.3378 shows that the concordance is not rejected at the $5 \%$ level of significance. The percentage of men who already do business is not statistically significantly different in comparison with the percentage of women who already do business.

Hypothesis "H2: men plan their own entrepreneurship more frequently than women" was not confirmed based on the consideration of only the data from students already doing business. 


\section{FUTURE RESEARCH DIRECTIONS}

Many surveys look at identifying incentives which lead to starting a business (Kurniawan, 2019; Verdugo, 2018; Chen, 2017 and others). However, it is important how the survey group is defined, because there are significant differences depending on age (for example, financial motivation is more important for younger entrepreneurs) and the education of respondents (Belás, Ključnikov \& Smrčka, 2016). The difference in education can be understood in terms of the educational level (secondary, university) but also in terms of the type of education (type of university). The results presented in this article apparently show that differences in intentions to go into business are actually influenced by the type of university currently studied at by the respondent. It would be appropriate to verify in further research whether the declared entrepreneurial intentions of students have subsequently been achieved. Such research would have to be of longitudinal character; however, its conclusions would be very valuable.

Gender differences in the attitude towards entrepreneurship is a rather disputable question. The causes of differences in gender participation in entrepreneurship were investigated by Acs et al. (2011), for example, who developed empirical studies presented at a conference organised by the Gender Equality for Development - World Bank Group and the Center for International Policy, University of Michigan, in June 2009, for example. Gender in the field of entrepreneurship has apparently been a topic for researchers for many years and these questions are still pertinent across continents (Le \& Raven, 2015; Bui, Kuan \& Chu, 2018). Belás, Ključnikov and Smrčka (2016) state that no differences were found in the intensity of incentives to go into business between genders. A number of studies come to the conclusion that gender influences entrepreneurial intentions (Molino et al., 2018; Perez-Quintana, 2017; Miranda et al., 2017; Francisco-Javier Caro-González, 2017). Gender differences in entrepreneurial self-efficacy are explained by cultural standards and stereotypes as well as other variables, such as supervisory experience, business process knowledge and educational level (Chowdhury, Endres \& Frye, 2019).

It was established, just as in this survey, that men consider starting a business more frequently than women. However, the subsequent analysis revealed that conclusions in the area of gender differ. For respondents not doing business, gender differences are identified, but for respondents doing business, gender distinctions become blurred. The same conclusion was made by Camelo-Ordaz, Diánez-González and Ruiz-Navarro (2016). They found that there are gender differences in the extent of entrepreneurial intentions but only considering those not doing business. Such disparities vanish in businesspersons. These findings are of great importance for future research. The fact whether a respondent considers starting a business or he/she already is in business, significantly changes his/her attitudes. Presumably, and further research should verify this, whether a similar change is typical for incentives initiating starting a business and incentives which subsequently maintain the entrepreneurial activities.

\section{CONCLUSION}

This survey looked at identifying variables influencing the entrepreneurial intentions of university students. The investigation included gender, mode of study (master's, bachelor), faculty and year of study as variables. The greatest influence on the willingness to start a business of the specified variables is from the type of university attended by students. The greatest interest in doing business is declared by students in the artistic field and students of economy and technology. It was further investigated whether men plan to start a business more frequently than 
women. The data obtained from a group of students not in business show gender differences, while the data processed from a group of students who already do business do not show such gender differences.

\section{ACKNOWLEDGMENT}

This research was supported by the Jan Evangelista Purkyně University in Ústí and Labem, Czech Republic [grant number UJEP-SGS-191-02-02].

\section{REFERENCES}

Acs, Z.J., Bardasi, E., Estrin, S. \& Svejnar, J. (2011). Introduction to Special Issue of "Small Business Economics" on Female Entrepreneurship in Developed and Developing Economies. Small Business Economics, 37(4), 393.

https://www.jstor.org/stable/41486141

Belás, J., Ključnikov, A., \& Smrčka, L. (2016). Motívy Pre Začatie Podnikania: Prípadová Štúdia Z Prostredia Msp. Scientific Papers of the University of Pardubice. Series D, Faculty of Economics \& Administration, 23(38), 5-17.

Bui, H. T. M., Kuan, A., \& Chu, T. T. (2018). Female Entrepreneurship in Patriarchal Society: Motivation and Challenges. Journal of Small Business and Entrepreneurship, 30(4), 325-343. https://doi.org/10.1080/08276331.2018.1435841

Camelo-Ordaz, C., Diánez-González, J. P., \& Ruiz-Navarro, J. (2016). The Influence of Gender on Entrepreneurial Intention: The Mediating Role of Perceptual Factors. Business Research Quarterly, 19(4), 261-277.

https://doi.org/10.1016/j.brq.2016.03.001

Campin, S., Barraket, J., \& Luke, B., (2013). Micro-Business Community Responsibility in Australia: Approaches, Motivations and Barriers. Journal of Business Ethics, 115(3), 489513.

https://doi.org/10.1007/s10551-012-1396-1

Chen, S. C., \& Elston, J. A. (2013). Entrepreneurial motives and characteristics: An Analysis of Small Restaurant Owners. International Journal of Hospitality Management, 35, 294305. https://doi.org/10.1016/j.ijhm.2013.07.002

Chen, M.-H., Wang, H.-Y., Chen, M.-H., \& Chang, Y.-Y. (2017). Understanding Creative Entrepreneurs' Intention to Quit: The Role of Entrepreneurial Motivation, Creativity, and Opportunity. Entrepreneurship Research Journal, 7(3).

https://doi.org/10.1515/erj-2016-0001

Chowdhury, S., Endres, M. L., \& Frye, C. (2019). The Influence of Knowledge, Experience, and Education on Gender Disparity in Entrepreneurial Self-efficacy. Journal of Small Business \& Entrepreneurship, 31(5), 371.

Francisco-Javier Caro-González, Helios Romero-Benabent, \& Isadora Sánchez Torné. (2017). The Influence of Gender on the Entrepreneurial Intentions of Journalism Students. Intangible Capital, (2), 430-478.

https://doi.org/10.3926/ic.927

Herring Shava, \& Willie T. Chinyamurindi. (2019). The Influence of Economic Motivation, Desire for Independence and Self-efficacy on Willingness to Become an Entrepreneur. The Southern African Journal of Entrepreneurship and Small Business Management, 11(1), 1-12. https://doi.org/10.4102/sajesbm.v11i1.234 
Hessels, J., van Gelderen, M., \& Thurik, R. (2008). Entrepreneurial Aspirations, Motivations, and their Drivers. Small Business Economics, 31(3), 323-339.

https://www.jstor.org/stable/40650947

Kurniawan, M. E. H., Yudoko, G., Basri, M. H., \& Umbara, A. N. (2019). Do Entrepreneurship Students Have an Intention to Become an Entrepreneur? Journal of Entrepreneurship Education, 22(2), 1-14.

Le, Q. V., \& Raven, P. V. (2015). Woman Entrepreneurship in Rural Vietnam: Success and Motivational Factors. Journal of Developing Areas, 49(2), 57-76. https://doi.org/10.1353/ jda.2015.0024

Miranda, F. J., Chamorro-Mera, A., Rubio, S., \& Pérez-Mayo, J. (2017). Academic Entrepreneurial Intention: The Role of Gender. International Journal of Gender and Entrepreneurship, 9(1), 66-86. https://doi.org/10.1108/IJGE-10-2016-0037

Molino, M., Dolce, V., Cortese, C. G., \& Ghislieri, C. (2018). Personality and Social Support as Determinants of Entrepreneurial Intention. Gender Differences in Italy. Plos One, 13(6), $1-19$. https://doi.org/10.1371/journal.pone.0199924

Nabi, G., Walmsley, A., Liñán, F., Akhtar, I., \& Neame, C. (2018). Does Entrepreneurship Education in the First Year of Higher Education Develop Entrepreneurial Intentions? The Role of Learning and Inspiration. Studies in Higher Education, 43(3), 452-467. https://doi.org/10.1080/03075079.2016.1177716

Raza, S. A., \& Irfan, M. (2017). Investigating the Intentions, Self-Efficacy and Motivators behind Entrepreneurial Decisions of Business Students. Bulletin of Education and Research, 39(3), 117-129.

Perez-Quintana, A., Hormiga, E., Martori, J. C., \& Madariaga, R. (2017). The Influence of Sex and Gender-role Orientation in the Decision to Become an Entrepreneur. International Journal of Gender and Entrepreneurship, 9(1), 8-30. https://doi.org/10.1108/IJGE-12-2015-0047

Verdugo, G. A. B. (2018). Innovative Self-concept of Micro-entrepreneurs: Perception of Barriers and Intention to Invest. BAR - Brazilian Administration Review, 15(2). ht p s:// doi.org/10.1590/1807-7692bar2018170085

Yildiz, K. (2018). The Effect of Career Decisions on Entrepreneurial Intention Levels of University Students Studying Sport Sciences. Journal of Education and Training Studies, 6, $13-18$. 